\title{
ПІДВИЩЕННЯ НАВЧАЛЬНИХ ДОСЯГНЕНЬ УЧНІВ 3 УКРАЇНСЬКОЇ ЛІТЕРАТУРИ В КОНТЕКСТІ КОМПЕТЕНТНІСНОГО НАВЧАННЯ
}

\author{
Мхитарян О. Д. \\ кандидат педагогічних наук, \\ старший викладач кафедри украӥнської мови і літератури \\ Миколаївський національний університет імені В. О. Сухомлинського \\ вул. Нікольська, 24, Миколаїв, Украӥна \\ orcid.org/0000-0002-4840-9708 \\ olgamhitaryan05@gmail.com
}

\author{
Ключові слова: учні з \\ низьким рівнем літературних \\ знань і вмінь, читаџька \\ компетентність, вивчення \\ художнього твору, \\ технологізачія навчально- \\ корекиійної роботи.
}

\begin{abstract}
У статті уточнено методологічні підходи до розв'язання проблеми формування читацької компетентності школярів із низьким рівнем успішності під час вивчення української літератури та визначено методичні умови цієї роботи. 3'ясовано зміст понять «учні з низьким рівнем навчальних досягнень», «компетенція», «компетентність» та подано їх тлумачення у площині методики навчання української літератури. Ключовими ідеями формування читацької компетентності «проблемних» учнів у ході вивчення художнього твору встановлено: необхідність урахування структури читацької компетентності як наукового підгрунтя розвивального навчання літератури; основними складниками читацької компетентності учнів є комплекс специфічних особистісних, когнітивних, естетико-комунікативних та ціннісних механізмів або сукупність визначених предметних компетенцій; діагностика реальних навчальних можливостей учнів як передумова індивідуалізації навчання; цілеспрямований розвиток особистісного потенціалу «неуспішних» учнів засобами мистецтва слова; потреба гуманізації педагогічних впливів; кореговане навчання літератури шляхом вивчення художнього твору в єдності думки та почуття; модельованість навчання літератури в напрямах корекції емоційно-вольових особливостей та розвитку пізнавальної сфери учнів; використання оптимального співвідношення методів навчання літератури, класифікованих за ознакою єдиного підходу до процесу навчання на методи організації, мотивації, контролю й самоконтролю читацької діяльності учнів із пізнавальними труднощами; технологізація корекційно-розвивальної роботи словесника на основі використання авторської типології навчальних завдань, спрямованих на підвищення ефективності читацької діяльності. Теоретичні положення проілюстровано на прикладі проєктування педагогічної допомоги для організації самостійного читання учнів, які мають низький рівень навчальних досягнень, специфіка якої полягає в розробленні орієнтовної системи запитань, що містить опорні вирази для ведення читацького щоденника такими учнями.
\end{abstract}




\title{
ENHANCING STUDENTS'ACHIEVEMENTS IN UKRAINIAN LITERATURE IN THE CONTEXT OF COMPETENCE LEARNING
}

\author{
Mkhytaryan O. D. \\ Candidate of Pedagogical Sciences, \\ Senior Lecturer at the Department of Ukrainian Language and Literature \\ V. O. Sukhomlynskyi Mykolaiv National University \\ Nikolska str., 24, Mykolaiv, Ukraine \\ orcid.org/0000-0002-4840-9708 \\ olgamhitaryan05@gmail.com
}

\begin{abstract}
Key words: students with a low level of literary knowledge and skills, reading competence, study of a work of art, technologicalization of educational and correctional work.
\end{abstract}

\begin{abstract}
The article clarifies the methodological approaches to solving the problem of forming the reading competence of students with low levels of success in the study of Ukrainian literature and identifies the methodological conditions of this work. The meaning of the concepts "students with a low level of academic achievement", "competence", "competence" is clarified and their interpretation in the field of methods of teaching Ukrainian literature is given. The key ideas of forming the reading competence of «problem» students in the study of a work of art are: the need to take into account the structure of reading competence as a scientific basis for the development of teaching literature; the main components of students' reading competence are a set of specific personal, cognitive, aesthetic-communicative and value mechanisms or a set of defined subject competencies; diagnosis of real learning opportunities of students as a prerequisite for individualization of learning; purposeful development of personal potential of «unsuccessful» students by means of the art of speech; the need for humanization of pedagogical influences; corrected teaching of literature by studying a work of art in the unity of thought and feeling; modeling of literature teaching in the directions of correction of emotional and volitional features and development of students' cognitive sphere; the use of the optimal ratio of methods of teaching literature, classified on the basis of a unified approach to the learning process on the methods of organization, motivation, control and self-control of reading activities of students with cognitive difficulties; technologicalization of correctional and developmental work of the linguist on the basis of use of the author's typology of the educational tasks directed on increase of efficiency of reading activity. Theoretical provisions are illustrated by the example of designing pedagogical assistance for the organization of independent reading of students with low levels of academic achievement, the specificity of which is to develop an indicative system of questions containing basic expressions for keeping a reading diary by such students.
\end{abstract}

Проблема якості літературної освіти набуває особливого значення в умовах радикального оновлення вітчизняної освітньої системи, спрямованого на розвиток дитини в інтересах іiї самої та людства загалом. Так, важливими складниками формули Нової української школи є новий зміст освіти, заснований на формуванні компетентностей, потрібних для успішної самореалізації в суспільстві, та орієнтація на потреби учня в освітньому процесі, дитиноцентризм [1, с. 7]. Однак об'єктивною реальністю сучасної школи $\epsilon$ масова неуспішність школярів, попри невичерпні потенційні можливості художнього твору для осо- бистісного становлення читача та впровадження прогресивних ідей вивчення літератури. На часі пошук ефективних шляхів розв'язання читацьких труднощів учнів у контексті сучасних освітніх викликів, зокрема компетентнісної спрямованості навчання української літератури.

Психолого-педагогічні основи формування читацької компетентності «проблемних» учнів грунтуються на фундаментальних дослідженнях учених із питань учнівської неуспішності (Ю. Бабанського, М. Мурачковського, В. Цетлін. Продуктивними $\epsilon$ досягнення педагогічної діагностики й корекційної педагогіки (О. Гонєєв, 
C. Гончаренко, В. Кащенко, В. Ліфінцева, Н. Пастушенко, Р. Пастушенко, I. Подласий, П. Підласий, В. Сластьонін та ін.), що містять узагальнення шляхів вивчення неуспішності й відставання учнів, визначення теоретико-практичних заходів подолання цих негативних проявів шкільної дійсності. Цінними є розроблені сучасними науковцями (О. Пєхота, А. Плигін, В. Паламарчук, М. Поташник, О. Савченко, С. Сисоєва, I. Якиманська) положення особистісно орієнтованого навчання й виховання завдяки інноваційним освітнім технологіям.

Для формування читацької компетентності учнів-читачів значущим виступає загальний аналіз проблеми реалізації компетентнісного підходу в сучасній українській школі (Н. Бібік, С. Бондар, О. Пометун, О. Савченко, С. Трубачева) та в освітніх системах зарубіжних країн (Н. Лавриченко, О. Локшина, О. Овчарук). Опорними в дослідженні є визначені вченими-методистами (О. Ісаєвою, Л. Мірошниченко, С. Паламар, А. Ситченком, А. Фасолею, Л. Фурсовою, В. Шуляром, Т. Яценко) особливості формування предметної літературної компетентності учнів, зокрема щодо необхідності уточнення суті й структури поняття та методичних умов його реалізації. Однак комплексний характер означеної проблеми спеціалістами досліджується у двох різних площинах: компетентнісного навчання літератури та підвищення навчальних досягнень учнів із української літератури (О. Мхитарян). Відтак процес формування читацької компетентності учнів із низьким рівнем літературної навченості вченими досі теоретично необгрунтований, унаслідок чого у шкільній практиці залишаються суперечності між невичерпним потенціалом мистецтва слова та нерозв'язаними проблемами емоційно-розумового розвитку школярів.

Мета статті полягає в уточненні методологічних підходів до розв'язання проблеми формування читацької компетентності школярів із низьким рівнем успішності у процесі вивчення української літератури та визначенні методичних умов цієї роботи.

Установлюючи чіткість категоріального апарату процесу компетентнісного навчання учнів із низьким рівнем літературного розвитку, зауважимо, що проблема розвивального навчання літератури ускладнюється відсутністю змістової єдності у визначенні якостей навчальних досягнень школярів, бо для позначення одного й того ж поняття у психолого-педагогічній літературі використовуються різні терміни - «слабовстигаючі» та «невстигаючі», «важкі», «педагогічно занедбані», «соціально дезадаптовані» учні, «діти зі зниженою научуваністю», «відстаючі в учінні» тощо [2, с. 44-45]. Переважно послуговуючись дефініцією «учні з низьким рівнем навчальних досягнень» відповідно до базових понять загальної педагогіки й методики предмета та зважаючи на провідні характеристики коментованого поняття, таких учнів визначаємо як тих, хто виявляє ознаки відставання в процесі здобуття знань і чиї результати навчання не відповідають державним стандартам загальноосвітньої підготовки школярів, конкретизованим у чинних навчальних програмах із літератури.

Оскільки результативними ознаками компетентнісного підходу $є$ сформованість компетенцій і компетентностей учнів, уточнимо зміст $\mathrm{i}$ цих дефініцій та взаємозв'язки між ними. Розводячи означені поняття, дотримуємося позиції науковців [3; 4], відповідно до якої компетенція співвідноситься 3 характеристиками, набутими учнем у процесі вивчення окремого навчального предмета (предметна компетенція), а компетентність - 3 метахарактеристиками, що складають ключову компетентність. Компетентнісна освіта спрямовується на досягнення результатів, якими $\epsilon$ ієрархічно підпорядковані ключова (базова), загальнопредметна і предметна (галузева) компетентності, тому читацьку компетенцію пояснюємо як відчужену від суб'єкта соціальну норму до освітньої підготовки учня, необхідну для його якісної продуктивної діяльності у сфері читацької діяльності. Натомість читацькою компетентністю, за висновками більшості вчених, називаємо набуту в процесі навчання літератури інтегровану здатність школяра, що складається зі знань, умінь, досвіду, цінностей і ставлення, які цілісно реалізуються у процесі практики.

У формувальному процесі важливою є структура читацької компетентності, що не обмежується розумінням лише психологічної або інтелектуальної даності особистості, а визначається рівнем успішності читацької діяльності учня, його здатністю до виконання значного спектру завдань із літератури та розв'язання проблем із метою досягнення позитивного результату. У розвивальному навчанні учнів із низьким рівнем навчальних досягнень спираємося на висновки фахівців про комплекс специфічних особистісних, когнітивних, естетико-комунікативних та иіннісних механізмів читацької компетентності, спрямованих на організацію та реалізацію ефективної естетичної взаємодії реципієнтів із художнім текстом [4, с. 252]. Крім того, оскільки рівень оволодіння учнями читацькою компетентністю визначається набутими предметними компетенціями, тлумачачи предметну компетентність як читацьку, за Т. Яценко, у іiі будові виділяємо сукупність таких предметних компетенцій, як-от: загальнокультурна, власне читацька, ціннісно-світоглядна, комунікативно-мовленнєва, інформачійно-комунікачійна [4, с. 253-254]. Відтак успішний результат підвищення навчальних досягнень учнів із 
літератури зумовлюється необхідністю цілеспрямованої уваги словесника до формування кожної 3 цих літературних компетенцій на усіх ланках педагогічного процесу, до яких зараховуються зміст, методи і форми діяльності, ії етапи й умови успішного проведення, результати та їх корекція.

Стратегічне значення для розвитку особистісного компонента читацької компетентності «неуспішних» учнів має принцип індивідуалізації їх навчання, що спирається на знання про їхні реальні навчальні можливості, до складу яких відносять: 1) особливості пізнавальної діяльності учнів (навченість (літературні знання, уміння), научуваність (здатність до навчання), надпредметні способи пізнання (загальнонавчальні вміння), ставлення до навчання, працездатність, темп роботи, самостійність); 2) сформованість психічних процесів, необхідних для розвитку читацьких якостей (сприймання, уява, мислення, пам'ять, мовлення, емоції та почуття, увага, воля); 3) специфіку особистісного розвитку школярів (потреби, інтереси, нахили, здібності, темперамент, характер); 4) особливості соціалізації учнів (родинне виховання, міжособистісні стосунки 3 учителями, однокласниками, неформальними групами спілкування) [2, с. 132-133]. Саме виявлення, структурування й цілеспрямований розвиток у процесі навчання суб' єктного досвіду кожного учня, тобто його уявлень і понять, способів пізнавальної діяльності, особистих ціннісних орієнтирів, за І. Якиманською, має бути провідним аспектом індивідуалізації навчання [7]. Крім того, реалізуючи цей принцип, забезпечуємо умови для вибору кожним школярем індивідуального освітнього шляху - мети, завдань, способів, темпу, форм, засобів, системи контролю й оцінки результатів літературної освіти.

Для подолання особистісних проблем розвитку читацької компетентності школярів важливим $є$ і принцип гуманізованого навчання літератури, що передбачає уникнення будь-якого педагогічного насильства завдяки діалогічному спілкуванню, провідною ознакою якого є прагнення вчителя побудувати добрі, людські стосунки з учнями на основі педагогічного оптимізму. Гуманізувати навчально-виховний процес потрібно завдяки прогнозуванню розвитку таких учнів із опорою на позитивне в них і перетворення всієї структури особистості через вплив на кращі якості. Головним завданням учителя під час розвивального навчання літератури стає не контроль та оцінювання школярів, а надання їм педагогічної допомоги, що активізує їхні внутрішні ресурси для подолання навчальних проблем.

Формування читацької компетентності учнів зі слабкою успішністю сприятиме їх особистісному становленню й за умови вивчення художнього твору в єдності думки й почуття, що не лише відповідає специфіці осягнення мистецтва слова, а й враховує типові пізнавальні й особистісні труднощі таких школярів. Сприймаючи літературні образи й картини як розумом, так і серцем, учні поступово долають притаманні їм вади художнього пізнання - інформативне, позаконтекстне, фрагментарне розуміння тексту та ін. У процесі літературного аналізу школярі розв'язують логічні й моральні суперечності, що потребує від них не лише напруженої роботи думки, а й певних переживань - радості, захоплення, суму, осуду, гніву тощо, без чого неможливо проникнути в ідейні шари твору, оцінити складові духовного світу персонажів. Адекватно засвоюючи зміст твору, переймаючись вчинками героїв, учні збагачуються досвідом моральної поведінки, унаслідок чого самовдосконалюються. Літературно-особистісне зростання учнів зі слабкою успішністю, що відбувається в їхньому чуттєвому й інтелектуальному відгуку на прочитане, водночас означатиме набуття ними загальнокультурної та иіннісно-світоглядної предметних компетенцій.

Цілеспрямований вплив на особистість із метою формування ii характерних властивостей дає змогу врахувати необхідність розроблення як змістового, так і формального аспектів цієї роботи, що зумовлює необхідність урахування принципу модельованості педагогічних впливів. Педагогічне моделювання передбачає проєктування чіткої динамічної системи розвивального навчання, що грунтується на органічному поєднанні в освітньому процесі навчально-виховних стратегій із діагностичними та корекційно-розвивальними. Навчально-виховні стратегії вивчення літератури задані в Державних стандартах і навчальних програмах, однак нормованість літературної освіти не заперечує відкритості освітніх перспектив для учнів із низьким рівнем знань і вмінь. Ідеться про обов'язкове забезпечення вільного переходу їх на інші освітні щаблі в межах основної літературної освіти, оскільки провідна особливість коригованого навчання полягає в організації пізнання кожного учня відповідно до максимуму його можливостей, особливо, якщо вони незначні [5, с. 107], а не в тому, щоб усі школярі мали високий і достатній рівень знань і вмінь. Діагностування індивідуальних особливостей і причин пізнавальних труднощів школярів, яке визначає всі педагогічні впливи, уможливлюється шляхом спеціально організованого моніторингу, що передбачає координацію роботи всіх необхідних учасників корекційного процесу - педагогів, психологів, лікарів, а не лише постійне цілеспрямоване спостереження словесника за «проблемними» діями учнів.

Зважаючи на пізнавальні труднощі неуспішних учнів, корекційно-розвивальні впливи 
словесника варто спрямовувати за двома взаємопов'язаними напрямами: 1) корекції емоційно-вольових особливостей школярів; 2) розвитку пізнавальної сфери учнів. Оскільки саме мотиви стимулюють учнів до активних пізнавальних дій, то корекція емоційно-вольових процесів вимагає особливої уваги вчителя насамперед до складових мотиваційної сфери: формування потреб самопізнання й самовдосконалення, інтересу учнів до літератури й процесу їі осягнення, виховання культури почуттів поряд із розвитком вольових якостей: цілеспрямованості, принциповості, самостійності, ініціативності, витримки, рішучості, наполегливості, організованості. Корекція пізнавальних процесів учнів спрямовується на розвиток тих психологічних процесів учнів, що сприяють повноцінному осягненню ними літератури: а) типу нервової системи (поняттєвий, образний); розумових операцій (виділення головного, порівняння, доведення, конкретизація, узагальнення); продуктивних ознак мислення (глибини, послідовності, самостійності, критичності, гнучкості, швидкості); б) провідного каналу (аудіальний, візуальний, кінестетичний) i властивостей сприймання твору (емоційність, точність, образність, цілісність, активність); в) відтворювальної і творчої уяви; г) особливостей пам'яті (типи, види) і процесу запам'ятовування (методи, засоби); г) усного й писемного мовлення (активний словник; грамотність, правильність, емоційність, образність, точність, чіткість, виразність); д) властивостей уваги (види; обсяг, розподіл і переключення). У такий спосіб компетентнісне навчання учнів із низьким рівнем навчальних досягнень виявлятиметься в конкретизації найближчих навчально-розвивальних та виховних цілей щодо кожного 3 них на основі діагностування їхніх можливостей і причин відставання, у відборі змісту та застосуванні окремих форм, методів, прийомів, засобів навчання завдяки педагогічній майстерності вчителя.

Оскільки розвиток особистості відбувається в процесі їі діяльності, у справі формування компетентного читача доречним $\epsilon$ використання оптимального співвідношення методів навчання літератури, погрупованих за єдиним підходом до процесу навчальної діяльності (Ю. Бабанський, M. Поташник). Відтак основними організаційними методами розвитку читацької компетентності учнів із низьким рівнем літературної навченості можуть бути: індивідуальна бесіда, виразно-художнє читання, переказування, усне малювання; ілюстрування, програвання, демонстрування; спостереження над текстом, планування, характеристика літературного героя, письмові роботи. Методами мотивації читацької діяльності учнів iз пізнавальними труднощами $\epsilon$ : забезпечення успіху в навчанні, літературні ігри, створення ситуацій інтересу й новизни; переконування й навіювання. Для контролю й самоконтролю пізнавальної діяльності «неуспішних» учнів доречно використовувати такі методи, як: індивідуальне опитування учнів із використанням додаткових i допоміжних запитань, пам'яток, алгоритмів і схем розумових дій; складання портфоліо тощо.

Осмислення шляхів подолання пізнавальних та особистісних труднощів учнів зі слабкою успішністю в аспекті формування когнітивного складника їх читацької компетентності, зумовлює технологізацію корекційно-розвивальних впливів педагога, сутність якої полягає в послідовній організації пізнавальної роботи учнів через типові навчальні дії [6, с. 84, 148-149], унаслідок чого формуються основні способи їх мислення, забезпечуються умови літературно-особистісного самовдосконалення. Для цілеспрямованого формування власне читацьької, комунікативно-мовленнєвої та інформаційно-комунікаційної компетенцій учнів, які виявляють читацькі труднощі, актуалізується використання авторської типології навчальних завдань, що спирається на врахування читацьких труднощів учнів. Так, перший тип завдань означає дії учнів, спрямовані на корекцію позитивної мотивації навчання, цілеспрямоване усунення недоліків у загальнонавчальних уміннях і психологічних процесах. Другий тип завдань грунтується на застосуванні алгоритмів розумових дій для вдосконалення літературних знань учнів. Третій тип завдань передбачає використання різноманітних регулятивів діяльності для закріплення в учнів читацьких умінь. Четвертий тип завдань пов'язаний із розвитком мовлення й творчих здібностей учнів [2, с. 147-149]. Особливістю пропонованої типології навчальних завдань $є$ їх змістово-процесуальна орієнтація та можливості для застосування вчителем диференційованої допомоги учням. Ідеться про орієнтовні основи розумових дій для здійснення навчальної діяльності - алгоритми, пам'ятки, інструктажі, таблиці, схеми та ін., що, не даючи готової відповіді, приводять школяра до самостійного розв'язання завдання. Важливо на основі психолого-педагогічного вивчення учня встановити оптимальну міру необхідної йому педагогічної допомоги, щоб він отримав реальні можливості для свого літературного розвитку.

Оскільки компетентний читач має бути здатним до самостійної пізнавальної діяльності як основи психічного розвитку особистості, розглянемо особливості надання педагогічної допомоги під час спеціально організованого й контрольованого вчителем самостійного читання учнів, які мають низький рівень навчальних досягнень. Спеціальним засобом формування читацької культури учнів із труднощами у навчанні 
виступатиме ведення ними читацьких щоденників, що сприяють розвитку навичок вдумливого читання, умінь пояснювати художні засоби, робити висновки, розширюють лексичний запас школярів. Із цією метою розробляється орієнтовна система запитань для ведення читацького щоденника учнями із низьким рівнем навчальних досягнень, що містить опорні слова й вирази, призначені оптимізувати їхню читацьку роботу:

1. Назва твору.

2. Прізвище, ім'я та по батькові автора.

3. Основні (важливі й цікаві) відомості про письменника й про твір:

- Особливості епохи, коли жив $i$ творив автор.

- Чим иікавий письменник як особистість $i$ митець слова? Які твори цьього автора вважаються найвизначнішими? 3 них я вже прочитав:...

- Що відомо про життеву основу твору й історію його написання та опублікування?

4. Яке первинне враження справив на тебе прочитаний твір:

- Що схвилювало, здалося дивним, незвичним або незрозумілим?

- Які запитання виникли під час читання?

- Про шуо ти хотів би поговорити після ознайомлення з текстом твору?

5. Стислий зміст (або докладний план) твору, що аналізується.

- За бажанням, намалюй ілюстрації на теми окремих епізодів, щуо тобі найбільше сподобалися.

6. Образи-персонажі, їх характеристика та значення у творі.

7. Головний герой, його характеристика та значення у творі:

1) змалювання зовнішності персонажа;

2) розкриття рис його характеру (за допомогою зображення вчинків, думок і почуттів; особливостей мови тощьо);

3) показ його ставлення до інших персонажів;

4) ставлення автора до свого героя;

5) пізнавальне й виховне значення цуього образу.

8. Хто з персонажів тобі найбільше сподобався й чим саме?

9. Художні засоби (епітети, порівняння тощо) або влучні слова й вирази, цікаві описи, використані автором, та їх значення у творі.

10. Пояснення лексичного значення слів, яких ти не зрозумів у тексті твору.

11. Тема твору (що змальовано автором у творі):
- Це розповідь, опис, роздум, змалювання ....

12. Ідея твору (про що автор хотів сказати цим твором, тобто його провідна думка):

- Це оспівування, звеличення, уславлення, піднесення, засудження, викриття, осуд, критика, заперечення, заклик до ....

13. Хто з письменників уже порушував схожі проблеми?

14. Жанр твору.

15. На основі первинних вражень і проведеного аналізу зроби висновок, чи сподобався тобі цей твір і чим саме:

- Прочитаний твір змусив мене задуматись над ...; дав змогу зрозуміти, що ...; спонукав переглянути ....

- Для мене творчість ијього письменника є ...

Результативність цієї навчально-розвивальної роботи значно підвищиться, якщо напрямами педагогічного керівництва самостійним читанням таких учнів обрати: виховання потреби в читанні; розгляд змісту прочитаного й спрямування читацьких інтересів; удосконалення культури читання; організацію тематики читання.

Отже, методичними умовами формування читацької компетентності учнів із низьким рівнем успішності під час вивчення української літератури є: 1) опора на структуру читацької компетентності як наукову основу корегованого навчання літератури; 2) особистісно-діяльнісна та гуманістична зорієнтованість розвитку читацьких якостей школярів із урахуванням специфіки мистецтва слова; 3 ) моніторинг вікових психо-розумових особливостей та індивідуальних можливостей учнів; 4) моделювання розвитку читацької компетентності таких школярів засобами художнього твору на основі технологізації корекційно-розвивальних впливів педагога; 5) використання оптимальної взаємодіï методів організації, мотивації та контролю й самоконтролю розвитку читацької діяльності учнів із низьким рівнем навченості; 6) проєктування навчальних завдань і відповідних їм алгоритмів подолання пізнавальних труднощів учнів; 7) увага до організації самостійного читання учнів та плекання їхніх читацьких інтересів.

Перспективи подальших досліджень проблеми полягають у проєктуванні конкретних навчальних моделей розвитку читацької компетентності учнів із низьким рівнем знань і вмінь у процесі вивчення ними творів української літератури.

\section{ЛІТЕРАТУРА}

1. Нова українська школа: Концептуальні засади реформування середньої школи. URL: http://mon.gov.ua/Новини\%202016/12/05/konczepcziya.pdf (дата звернення: 20.10.2020).

2. Мхитарян О. Підвищення навчальних досягнень учнів з української літератури : монографія. Миколаїв : Іліон, 2014. 232 с. 
3. Локшина О.І. Зміст шкільної освіти в країнах Європейського Союзу: теорія і практика (друга половина XX - початок XXI ст.) : монографія. Київ : Богданова А.М., 2009. 404 с.

4. Яценко Т.О. Тенденції розвитку методики навчання української літератури в загальноосвітніх навчальних закладах (друга половина XX - початок XXI століття) : монографія. Київ : Педагогічна думка, 2016. 360 с.

5. Поташник М.М. Требования к современному уроку : метод. пособ. Москва : Центр педагогического образования, 2008. $272 \mathrm{c}$.

6. Ситченко А.Л. Навчально-технологічна концепція літературного аналізу : монографія. Київ : Ленвіт, 2004. $304 \mathrm{c.}$

7. Якиманская И.С. Технология личностно-ориентированного обучения в современной школе. Москва : Сентябрь, 2000. 176 с.

\section{REFERENCES}

1. Nova ukraYinska shkola: KontseptualnI zasadi reformuvannya serednoYi shkoli [The new Ukrainian school: Conceptual principles of secondary school reform]. URL: http://mon.gov.ua/Novini 2016/12/05/ konczepcziya.pdf (data zvernennya: 20.10.2020).

2. Mkhytarian O. (2014). Pidvyshchennia navchalnykh dosiahnen uchniv z ukrainskoi literatury [Improvement of student achievements in Ukrainian literature]. Mykolaiv : Ilion, 232.

3. Lokshyna O. I. (2009). Zmist shkilnoi osvity v krainakh Yevropeiskoho Soiuzu: teoriia i praktyka (druha polovyna $\mathrm{KhKh}$ - pochatok KhKhI st.) [Contents of school education in the countries of the European Union: theory and practice (second half of the XX - beginning of the XXI century)]. K. : Bohdanova A. M., 404.

4. Iatsenko T. O. (2016). Tendentsii rozvytku metodyky navchannia ukrainskoi literatury v zahalnoosvitnikh navchalnykh zakladakh (druha polovyna KhKh - pochatok KhKhI stolittia) [Trends in the development of the methodology of teaching Ukrainian literature in general education institutions (second half of the XX - beginning of the XXI century)]. Kyiv : Pedahohichna dumka, 360.

5. Potashnyk M. M. (2008). Trebovanyia k sovremennomu uroku [Requirements for a modern lesson]. Moskva: Tsentr pedahohycheskoho obrazovanyia, 272.

6. Sitchenko A. L. (2004). Navchalno-tekhnologichna koncepciya literaturnogo analizu [Education technology concept literary analysis]. Kyiv : Lenvit, 304.

7. Yakymanskaya Yu. S. (2000). Texnologyya lychnostno-oryentyrovannogo obuchenyya v sovremennoj shkole [The technology of personal-oriented learning in modern school]. Moskva : Sentyabr, 176. 